\title{
Effect of Different Cutting Heights of Mechanically Pruned Grapevines cv. Merlot Over Three Consecutive Seasons
}

\author{
M.C. Peppi*, E. Kania, R. Talep, P. Castro, G. Reginato \\ Departamento de Producción Agrícola, Universidad de Chile, Av. Santa Rosa 11315, La Pintana, Santiago, Chile
}

Submitted for publication: March 2017

Accepted for publication: September 2017

Keywords: Labour, yield, decline, sustainable production, man-day

\begin{abstract}
The mechanisation of various vineyard operations reduces production costs and labour requirements, thus allowing for the more efficient management of larger vineyards. However, pruning mechanisation has been associated with yield decline (a decrease in fruit production due to the elongation of the fruiting positions out of the trellis system area), over cropping and unstable yields. Furthermore, manual followup has been a common practice for most vineyards subjected to mechanised pruning. A Merlot vineyard was studied for three consecutive seasons in terms of its vegetative and productive aspects, and hand pruning was compared with mechanised alternating pruning strategies. Bud burst was more successful in hand-pruned vines compared to mechanically pruned vines. However, hand pruning took longer and produced a lower yield compared to mechanical pruning. Traditional high $(25 \mathrm{~cm}$ above the cordon wire) mechanical pruning showed deteriorating characteristics over time in vegetative and yield parameters. Vines pruned at a lower height $(12 \mathrm{~cm}$ above the cordon wire) in one of the three seasons maintained high production. Despite higher yields, fruit soluble solids, pH and titratable acidity were not altered. The quantity of second-crop fruit from lateral shoots was small and was very similar among treatments. Mechanical pruning at a lower height in one season in general reduces the annual potential yield, but the average and cumulative effects over the years improve compared to using just traditional high mechanical pruning. These long-term effects make it feasible to fully mechanise vineyard pruning and maintain high yields.
\end{abstract}

\section{INTRODUCTION}

The need to reduce production costs and the shortage of labour have led to a significant increase in mechanically farmed wine grape area. Mechanisation has been implemented for harvesting, as well as for some canopy management and pruning. The approximately 142000 ha of wine grapes planted in Chile (SAG, 2015) must be managed efficiently to maintain yields and quality levels; however, in some cases mechanised pruning has resulted in a premature decline in vineyard production, or over cropping in the first seasons followed by decreased yields and variations in fruit quality (Reynolds, 1988). These aspects have forced manual followup pruning, thus dismissing previous savings in labour (Lopes et al., 2000; Keller et al., 2004; Gatti et al., 2011).

Harvest mechanisation began in the late 1960s and, although certain problems were experienced initially (Winkler et al., 1957; Morris \& Cawthon, 1981), continuous research over the years has resolved most issues and has helped to increase its popularity (Intrieri \& Poni, 1990; Clingeleffer, 2000; Morris, 2007; Dokoozlian, 2013). Some of the common problems of mechanical pruning are linked to unbalanced fruit-leaf ratios, which determine productivity changes over the years, from excessive to low yields (Reynolds, 1988; Martínez de Toda \& Sancha, 1999; Howell, 2001; Morris, 2007; Terry \& Kurtural, 2011). However, there are also examples from mechanically pruned vines with higher yields and no over cropping (Keller et al., 2004). Another strategy used to mechanise pruning without affecting yield sustainability is the use of manual followup pruning, fruit thinning and/or shoot thinning during the season in order to remove excessive crop (Martínez de Toda \& Sancha, 1999; Gatti et al., 2011). However, this strategy decreases the labour-related benefits of mechanisation. Most vineyards do not consider any regular annual hand pruning following mechanised pre-pruning, and yield decline over the years is assumed to be part of the costs of the productive system. Only once yields decrease substantially is hand pruning utilised to rejuvenate and balance the vineyard, thus increasing labour costs and decreasing yield during that year. Dokoozlian (2013) estimated that, in California, only about $5 \%$ of vineyards used for wine grape production are mechanically pruned with little or no manual follow-up. In Washington State, most vineyards mechanically pre-pruned

\footnotetext{
*Corresponding author: E-mail address: mpeppi@uchile.cl

Acknowledgements: This study was funded by a grant from the Región del Libertador General Bernardo O'Higgins, Chile. We are thankful for the collaboration of Viña Caliterra
} 
are later pruned manually (Keller et al., 2004). In other wine grape-growing regions, including Chile, the situation is similar.

Savings in pruning and related operations would help widespread mechanisation due to its labour efficiency. However, there is little information on how to maintain quality and high levels of production using mechanical pruning without any manual input so as to minimise production variability throughout vineyard life. One approach to maintain high yields in mechanically pruned vines has been to use different hedge shapes, with some offset of the shape and alternating sides every year (Freeman \& Cullis, 1981). Nevertheless, although the results were promising in terms of labour savings, the yields were low compared to the controls. Besides the low yields there also was a strong variety dependence, which affected which hedge shape was the best. Keller et al. (2004) suggested options to manage production decline in mechanised vineyards, like alternating the distance of pruning cuts from the cordon or a minimal pruning approach.

The aim of this study was to determine the effect of some very simple mechanical pruning variations in cut height on the productive and vegetative parameters of a Vitis vinifera Merlot vineyard in central Chile that was already being mechanically pruned in order to reduce labour requirements.

\section{MATERIALS AND METHODS}

The study, conducted from the 2013/2014 season through the 2015/2016 season, was carried out in an own-rooted Merlot vineyard, planted in 1996 on a vertical shoot-positioned trellis system, with rows oriented NE-SW and a $2.0 \times 1.5 \mathrm{~m}$ spacing, in El Huique, Peralillo, Libertador General Bernardo

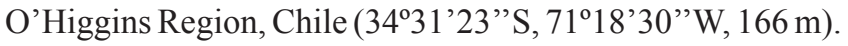
The soil is a clay loam from the Almahue series, classified as an aquic haploxererts (vertisol) (CIREN, 2010). The climate is Mediterranean, warm and mild (Csa by Köppen-Geiger), with an average of $710 \mathrm{~mm}$ of rainfall concentrated in the winter. However, the study period coincided with a drought, and rainfall was 422, 568 and $355 \mathrm{~mm}$ in 2013, 2014 and 2015 respectively. Vines were drip-irrigated with one $2 \mathrm{~L} / \mathrm{h}$ dripper per plant. Each year the plants were fertilised with potassium and nitrogen according to the standard vineyard practice. Nutrients were distributed equally at bud burst, after fruit set and prior to véraison. During the 2013/2014 season, $69 \mathrm{~kg} / \mathrm{ha}$ of $\mathrm{N}$ and $99 \mathrm{~kg} / \mathrm{ha}$ of $\mathrm{K}$ were applied, followed by $138 \mathrm{~kg} / \mathrm{ha}$ of $\mathrm{N}$ and $198 \mathrm{~kg} / \mathrm{ha}$ of $\mathrm{K}$ in the second season, and $239 \mathrm{~kg} / \mathrm{ha}$ of $\mathrm{N}$ and $411 \mathrm{~kg} / \mathrm{ha}$ of $\mathrm{K}$ during the last season of the study. Plants were trained to a bilateral cordon and trellised with a cordon wire at $80 \mathrm{~cm}$ and foliage wires at $120 \mathrm{~cm}$, and had been mechanically pruned for five years (since 2008).

Standard vineyard practices were carried out to control powdery mildew and botrytis, and irrigation practices were established according to the evaluation of soil pits. Vines were pruned by hand or mechanically. Hand pruning (S) consisted of 12 two-bud spurs per plant, and mechanical pruning was performed $25 \mathrm{~cm}$ above the cordon wire $(\mathrm{H})$ or $12 \mathrm{~cm}$ above the cordon wire $(\mathrm{L})$. Treatments were consecutive hand spur pruning or alternated mechanical pruning at different heights from the cordon wire: T1, SSS; T2, SLH; T3, HHH; T4,
HLH; T5, LLL; and T6, LHH.

Mechanical pruning was performed with a pre-pruning machine (MM, Portezuelo PVR model 2007) (2013-11-07, 2014-18-07, 2015-17-07), and one week later shoots growing towards the alley between rows were cut with a hedger (VBC-C6). The same hedger was then used once during the growing season, in all treatments alike, so that shoot length was equal among treatments. On each treatment, the total time required for pruning was recorded and expressed as man-days (MD, the amount of work one person does in a nine-hour day) per ha. Each year, harvest was on the same date for all treatments, determined by the vineyard operations manager and established by commercial total soluble solids accumulation (TSS; $23^{\circ}$ Brix average). Harvest dates were 10 March, 31 March and 29 March in 2014, 2015 and 2016 respectively. The 2016 harvest did not reach $23^{\circ}$ Brix, but commercial harvest was performed anyway since sugar accumulation had almost stopped and there was a high risk of fruit loss due to fungal pressure in the vineyard. Evaluations included yield per plant, bunch mass, fruit TSS and titratable acidity (TA). Second-crop fruit was picked on the same date as the commercial crop and kept separately for analysis. After leaf fall, when vegetative elements were easier to distinguish, the following characteristics were evaluated: number of nodes left per plant, number of renewal shoots (originating from old wood) and season bud burst (expressed as number of sprouted nodes and as \% of nodes sprouted per spur).

The design was a completely randomised block with six treatments and six replicates per treatment, and the block corresponded to the row. The experimental unit was a set of 20 adjacent plants (four sets of five plants between two posts). Subsampling was performed on three plants in each experimental unit. All bunches and second-crop fruit from these three plants were counted and weighed. Bunches were pressed to obtain juice, which was used for TSS, $\mathrm{pH}$ and TA measurements. Juice TSS were determined at $20^{\circ} \mathrm{C}$ with a hand-held refractometer (PR32, Atago Co. Ltd., Tokyo, Japan), $\mathrm{pH}$ was registered using a $\mathrm{pH}$ meter (PHS-3BW, Bante Instrument; Shanghai, China), and for TA $20 \mathrm{ml}$ of juice were titrated with $\mathrm{NaOH} 0.1 \mathrm{M}$ to an endpoint of $\mathrm{pH}$ 8.2 using the same $\mathrm{pH}$ meter. TA was calculated and reported as $\mathrm{g} / \mathrm{L}$ of tartaric acid.

Completely randomised block designs can be inefficient and unable to recognise spatial variability in study sites. For this reason it is necessary to pay special attention to possible variability in field data, such as spatial autocorrelation when variables are analysed. Models including spatial correlations correct the means of each treatment by the effect of the site where treatments were randomly placed. To model systematic effects of possible experimental site variability, the row and position on the row were recorded for each plant.

Different mixed linear models were adjusted, considering the treatments as fixed effect and blocks as random effect. Subsampling within each experimental unit was modelled considering the experimental unit as random effect.

Models with variance heterogeneity between treatments and models including a spatial correlation function (exponential, Gaussian, linear, others) were considered. Models with heterogeneous variances were compared 
with models with homogeneous variances, and spatial correlation models were compared with independent error variance models. AIC (Aikaike Information Criterion) and BIC (Bayesian Information Criterion) indices were used for model selection (Di Rienzo et al., 2011). Lower values for these criteria indicated the best model.

In the case of finding statistically significant differences between treatments, the multiple comparison test of Fisher's LSD to a 5\% level of significance was used. All analyses were processed with the statistical software, Infostat (Di Rienzo et al., 2016).

\section{RESULTS AND DISCUSSION}

The results for pruning time are presented for each year, along with the average over the three seasons. As expected, mechanical pruning was considerably faster than hand pruning, taking less than half a man-day (MD) per ha instead of at least $7 \mathrm{MD} /$ ha for hand spur pruning (Table 1). Time savings with mechanical pruning have been recorded for single-curtain Concord vines (Morris et al., 1975), Cabernet Sauvignon (Freeman \& Cullis, 1981), Croatina (Poni et al., 2004), as well as Barbera (Gatti et al., 2011). Archer and Van Schalkwyk (2007) required between 28.0 and $91.4 \mathrm{~h}$ per ha to hand prune different varieties in different locations, whilst mechanical pruning ranged from 12.4 to $41.3 \mathrm{~h}$ per ha. Our results for hand pruning ranged from 67.1 to $115.8 \mathrm{~h}$ per ha (MD x $9 \mathrm{~h})$, but our mechanical pruning times were considerably lower (3.9 to $4.3 \mathrm{~h}$ per ha). Moreover, the times required for mechanical pruning during the three seasons of the study were uniform, whilst in hand pruning there was considerable variability. Particularly, more time was required (almost $13 \mathrm{MD} / \mathrm{ha}$ ) when attempting the renewal of mechanically pruned plants. Hand spur-pruned vines (that were previously machine pruned) were easier to prune each year due to vine shape refurbishment, although pruning time required was always considerably higher than for mechanically pruned vines. The same sort of disparities in vine features can explain the differences in hand and mechanical pruning times reported for Merlot by other authors (Archer \& Van Schalkwyk, 2007)

Bud burst (sprouted nodes per spur) and renewals were always higher in vines pruned manually (Tables 2 and 3). The lowest bud burst percentage observed in mechanical pruning was offset by the higher number of nodes per spur and nodes per plant (Tables 3 and 4). Although significant, mechanically pruned elements, despite their greater length, did not show a high increase in nodes per spur, but the number of positions in the cordon (spurs per plant) were almost triple that of hand pruning (Tables 2 and 4). Roughly, mechanically pruned plants, regardless of the machine height at operation, had three times more plant nodes compared to hand pruning. There are various examples with similar results in node number per plant for different varieties: simulated mechanised pruning in Grenache tripled the node number compared to hand pruning (Martínez de Toda \& Sancha, 1999), mechanically pruned Cabernet Sauvignon plants in a California sprawl system quadrupled the plant bud number (Dokoozlian, 2013), and mechanised pruning of Concord GDC or single curtain-trellised vines had approximately three times more nodes than hand-pruned plants (Morris \& Cawthon, 1981; Keller et al., 2004). Bud number per plant has been a concern because of vine balance, yield and grape composition (Morris et al., 1975; Morris \& Cawthon, 1981; Keller et al., 2004; Poni et al., 2004; Dokoozlian, 2013). Nonetheless, mechanised pruning not only increases nodes per plant but also alters bud burst percentage and node position (Martínez de Toda \& Sancha, 1999; Lopes et al., 2000; Keller et al., 2004), which somewhat explains yield variations after continuous mechanical pruning. The type of pruning drastically altered the shoot number and location on the cordon. Hand spur-pruned plants had consistently more new shoots (Table 3) and, after three seasons, had an average of 13.4 shoots arranged on the cordon; i.e. 13.4 pruning alternatives (Table 4). Mechanically pruned plants, on the other hand, had their pruning alternatives reduced to less than half (Tables 3 and 4). Vines pruned by hand one year (T2) and vines pruned mechanically at $12 \mathrm{~cm}$ above the cordon wire for three consecutive seasons (T5) showed

TABLE 1

Pruning time in man-days/ha (MD/ha) from different treatments in a Merlot vineyard in El Huique, Chile

\begin{tabular}{|c|c|c|c|c|}
\hline \multirow[b]{2}{*}{ Treatment } & \multicolumn{4}{|c|}{ Pruning time $\left({ }^{1} \mathrm{MD} / \mathrm{ha}\right)$} \\
\hline & 2013-2014 & 2014-2015 & $2015-2016$ & $\begin{array}{l}\text { Average for three } \\
\text { seasons }\end{array}$ \\
\hline T1 (SSS) & $12.87 \mathrm{a}$ & $9.14 \mathrm{a}$ & $7.46 \mathrm{a}$ & $9.83 \mathrm{a}$ \\
\hline T2 (SLH) & $12.87 \mathrm{a}$ & $0.41 \mathrm{~b}$ & $0.41 \mathrm{~b}$ & $4.56 \mathrm{~b}$ \\
\hline T3 (HHH) & $0.47 \mathrm{~b}$ & $0.47 \mathrm{~b}$ & $0.47 \mathrm{~b}$ & $0.47 \mathrm{c}$ \\
\hline T4 (HLH) & $0.47 \mathrm{~b}$ & $0.48 \mathrm{~b}$ & $0.48 \mathrm{~b}$ & $0.48 \mathrm{c}$ \\
\hline T5 (LLL) & $0.46 \mathrm{~b}$ & $0.46 \mathrm{~b}$ & $0.46 \mathrm{~b}$ & $0.46 \mathrm{c}$ \\
\hline T6 (LHH) & $0.46 \mathrm{~b}$ & $0.43 \mathrm{~b}$ & $0.43 \mathrm{~b}$ & $0.44 \mathrm{c}$ \\
\hline
\end{tabular}

${ }^{1} \mathrm{MD}=$ the amount of work one person does in a nine-hour day.

The S, L and $\mathrm{H}$ for each treatment refer to $\mathrm{S}$ : hand pruning, 12 two-bud spurs per plant; $\mathrm{H}$ : mechanical pruning $25 \mathrm{~cm}$ above the cordon wire; L: mechanical pruning $12 \mathrm{~cm}$ above the cordon wire; with each capital letter corresponding to one season from the three consecutive years of the study.

Means with the same letters in the columns are not significantly different. Fisher's LSD $(\mathrm{p} \leq 0.05)$ 
TABLE 2

Spurs per plant, nodes per spur and bud burst percentage (\%) of Merlot vines hand or mechanically pruned for three seasons in El Huique, Chile.

\begin{tabular}{llllllllll}
\hline & \multicolumn{3}{c}{ Spurs $^{1}$ per plant } & \multicolumn{3}{c}{ Nodes $^{2}$ per spur } & \multicolumn{3}{c}{ Bud burst (\%) } \\
\cline { 2 - 9 } Treatment & $2013 / 14$ & $2014 / 15$ & $2015 / 16$ & $2013 / 14$ & $2014 / 15$ & $2015 / 16$ & $2013 / 14$ & $2014 / 15$ & $2015 / 16$ \\
\hline $1(\mathrm{SSS})$ & $9.1 \mathrm{~b}$ & $11.7 \mathrm{~b}$ & $11.6 \mathrm{~b}$ & $1.8 \mathrm{c}$ & $1.5 \mathrm{c}$ & $2.1 \mathrm{a}$ & $86.5 \mathrm{a}$ & $92.3 \mathrm{a}$ & $94.5 \mathrm{a}$ \\
$2(\mathrm{SLH})$ & $9.1 \mathrm{~b}$ & $23.2 \mathrm{a}$ & $25.6 \mathrm{a}$ & $1.8 \mathrm{c}$ & $2.5 \mathrm{ab}$ & $2.2 \mathrm{a}$ & $86.5 \mathrm{a}$ & $62.9 \mathrm{~b}$ & $68.3 \mathrm{bc}$ \\
$3(\mathrm{HHH})$ & $26.5 \mathrm{a}$ & $26.4 \mathrm{a}$ & $25.8 \mathrm{a}$ & $2.8 \mathrm{a}$ & $2.6 \mathrm{ab}$ & $2.3 \mathrm{a}$ & $62.1 \mathrm{c}$ & $61.6 \mathrm{~b}$ & $68.7 \mathrm{bc}$ \\
$4(\mathrm{HLH})$ & $26.5 \mathrm{a}$ & $23.2 \mathrm{a}$ & $26.2 \mathrm{a}$ & $2.8 \mathrm{a}$ & $2.4 \mathrm{ab}$ & $2.9 \mathrm{a}$ & $62.1 \mathrm{c}$ & $64.1 \mathrm{~b}$ & $63.5 \mathrm{c}$ \\
$5(\mathrm{LLL})$ & $25.8 \mathrm{a}$ & $23.3 \mathrm{a}$ & $25.2 \mathrm{a}$ & $2.3 \mathrm{~b}$ & $2.3 \mathrm{~b}$ & $2.3 \mathrm{a}$ & $70.8 \mathrm{~b}$ & $66.4 \mathrm{~b}$ & $70.2 \mathrm{~b}$ \\
$6(\mathrm{LHH})$ & $25.8 \mathrm{a}$ & $26.9 \mathrm{a}$ & $27.4 \mathrm{a}$ & $2.3 \mathrm{~b}$ & $2.7 \mathrm{a}$ & $2.7 \mathrm{a}$ & $70.8 \mathrm{~b}$ & $61.6 \mathrm{~b}$ & $63.8 \mathrm{c}$ \\
\hline
\end{tabular}

${ }^{1}$ Spurs or spur position, ${ }^{2}$ Bud number per pruned element

The S, L and $\mathrm{H}$ for each treatment refer to S: hand-pruning, 12 two-bud spurs per plant; $\mathrm{H}$ : mechanical pruning $25 \mathrm{~cm}$ above the cordon wire; L: mechanical pruning $12 \mathrm{~cm}$ above the cordon wire; with each capital letter corresponding to one season from the three consecutive years of the study.

Means with the same letters in the columns are not significantly different. Fisher's LSD $(p \leq 0.05)$

TABLE 3

Renewals on the cordon and total renewal shoots of Merlot vines hand or mechanically pruned for three seasons in El Huique, Chile.

\begin{tabular}{lllllll}
\hline Treatment & \multicolumn{3}{c}{ Cordon renewal shoots } & \multicolumn{3}{c}{ Total renewal shoots per vine } \\
\cline { 2 - 7 } & $2013 / 14$ & $2014 / 15$ & $2015 / 16$ & $2013 / 14$ & $2014 / 15$ & $2015 / 16$ \\
\hline $1(\mathrm{SSS})$ & $20.5 \mathrm{a}$ & $11.8 \mathrm{a}$ & $7.8 \mathrm{a}$ & $28.4 \mathrm{a}$ & $21.4 \mathrm{a}$ & $15.8 \mathrm{a}$ \\
$2(\mathrm{SLH})$ & $20.5 \mathrm{a}$ & $5.1 \mathrm{~b}$ & $1.3 \mathrm{c}$ & $28.4 \mathrm{a}$ & $10.2 \mathrm{bc}$ & $4.3 \mathrm{c}$ \\
$3(\mathrm{HHH})$ & $5.8 \mathrm{~b}$ & $3.5 \mathrm{c}$ & $1.4 \mathrm{c}$ & $10.8 \mathrm{c}$ & $7.1 \mathrm{~d}$ & $4.4 \mathrm{c}$ \\
$4(\mathrm{HLH})$ & $5.8 \mathrm{~b}$ & $4.3 \mathrm{bc}$ & $1.7 \mathrm{c}$ & $10.8 \mathrm{c}$ & $10.0 \mathrm{bc}$ & $2.7 \mathrm{~d}$ \\
$5(\mathrm{LLL})$ & $8.3 \mathrm{~b}$ & $4.5 \mathrm{bc}$ & $5.0 \mathrm{~b}$ & $16.9 \mathrm{~b}$ & $11.3 \mathrm{~b}$ & $8.8 \mathrm{~b}$ \\
$6(\mathrm{LHH})$ & $8.3 \mathrm{~b}$ & $3.7 \mathrm{bc}$ & $1.8 \mathrm{c}$ & $16.9 \mathrm{~b}$ & $7.9 \mathrm{~cd}$ & $3.8 \mathrm{c}$ \\
\hline
\end{tabular}

The S, L and $\mathrm{H}$ for each treatment refer to S: hand-pruning, 12 two-bud spurs per plant; $\mathrm{H}$ : mechanical pruning $25 \mathrm{~cm}$ above the cordon wire; L: mechanical pruning $12 \mathrm{~cm}$ above the cordon wire; with each capital letter corresponding to one season from the three consecutive years of the study.

Means with the same letters in the columns are not significantly different. Fisher's LSD $(p \leq 0.05)$

TABLE 4

Total nodes in spurs, bud burst from spurs per plant, bud burst percentage (\%) and renewal number position of Merlot vines hand or mechanically pruned in El Huique, Chile, average over three seasons (from 2013/14 to 2015/16).

\begin{tabular}{lllllll}
\hline Treatment & $\begin{array}{l}\text { Spurs }^{1} \\
\text { per plant }\end{array}$ & $\begin{array}{l}\text { Nodes }^{2} \\
\text { per spur }\end{array}$ & $\begin{array}{l}\text { Nodes }^{3} \\
\text { per plant }\end{array}$ & Bud burst (\%) & $\begin{array}{l}\text { Cordon renewal } \\
\text { shoots }\end{array}$ & $\begin{array}{l}\text { Total renewal } \\
\text { shoots per vine }\end{array}$ \\
\hline $1(\mathrm{SSS})$ & $10.8 \mathrm{c}$ & $1.8 \mathrm{~d}$ & $19.7 \mathrm{~d}$ & $91.6 \mathrm{a}$ & $13.4 \mathrm{a}$ & $21.9 \mathrm{a}$ \\
$2(\mathrm{SLH})$ & $18.5 \mathrm{~b}$ & $2.2 \mathrm{c}$ & $42.2 \mathrm{c}$ & $73.2 \mathrm{~b}$ & $8.9 \mathrm{~b}$ & $14.3 \mathrm{~b}$ \\
$3(\mathrm{HHH})$ & $26.5 \mathrm{a}$ & $2.5 \mathrm{abc}$ & $66.3 \mathrm{ab}$ & $64.1 \mathrm{c}$ & $3.6 \mathrm{~d}$ & $7.4 \mathrm{~d}$ \\
$4(\mathrm{HLH})$ & $24.3 \mathrm{a}$ & $2.9 \mathrm{a}$ & $66.3 \mathrm{ab}$ & $63.2 \mathrm{c}$ & $3.9 \mathrm{~d}$ & $7.8 \mathrm{~d}$ \\
$5(\mathrm{LLL})$ & $24.2 \mathrm{a}$ & $2.4 \mathrm{bc}$ & $56.7 \mathrm{~b}$ & $69.2 \mathrm{~b}$ & $5.9 \mathrm{bc}$ & $12.4 \mathrm{~b}$ \\
$6(\mathrm{LHH})$ & $26.5 \mathrm{a}$ & $2.6 \mathrm{ab}$ & $66.9 \mathrm{a}$ & $65.4 \mathrm{c}$ & $4.6 \mathrm{~cd}$ & $9.6 \mathrm{c}$ \\
\hline
\end{tabular}

${ }^{1}$ Spurs or spur position, ${ }^{2}$ Bud number per pruned element, ${ }^{3}$ Total nodes per plant

The S, L and $\mathrm{H}$ for each treatment refer to S: hand-pruning, 12 two-bud spurs per plant; $\mathrm{H}$ : mechanical pruning $25 \mathrm{~cm}$ above the cordon wire; L: mechanical pruning $12 \mathrm{~cm}$ above the cordon wire; with each capital letter corresponding to one season from the three consecutive years of the study.

Means with the same letters in the columns are not significantly different. Fisher's LSD $(p \leq 0.05)$ 
intermediate values of cordon renewal shoots (Tables 3 and 4). Mechanical pruning at $25 \mathrm{~cm}(\mathrm{~T} 3, \mathrm{~T} 4$ and $\mathrm{T} 6)$ presented the lowest renewal values (Tables 3 and 4), which is a sign of the production decline commonly observed in mechanically pruned vineyards. However, T6 was also similar to T5 (Tables 3 and 4), another indication that lowering the height of the pruning one season helps to maintain vineyard growth and sustainability. In addition, total shoot number from cordons and spurs were considerably higher in plants pruned by hand (Tables 3 and 4). The most detrimental situation was observed in the traditional high mechanically pruned plants, which had slightly more than seven total renewal shoots per plant (Table 4). In terms of cordon renewal and total renewal shoots, treatments with low mechanical pruning one season (T4 and T6) showed the same or better behaviour than T3 plants (Tables 3 and 4). The low renewal situation was particularly tough in the third season (Table 3 ), where mechanically pruned plants (T2, T3, T4, T6) had a total of only between 2.7 and 4.4 renewal shoots per plant. During the third season, only T5 (plants always pruned low) showed more satisfactory values (8.8 renewal shoots/plant), but far from the 15.8 shoots of hand-pruned plants. Keller et al. (2004) observed different behaviour in mechanically pruned Concord grapes; although the vines also exhibited the negative correlation between node number and bud burst, the count shoots ("renewal shoots") were higher in mechanically pruned vines. This difference probably responded to the variety and higher capacity associated with the Concord vines in the study of Keller et al. (2004).

Cane renewal influenced yield components (Tables 3 and 4), therefore not only new shoots but also total fruit mass have to be considered. Mechanically pruned vines showed higher bunch number, regardless of pruning height, except for in the third season when yields were particularly high and no differences in bunches per plant, or in yield, were observed (Table 5). Average total yield was higher on mechanically pruned vines (Table 6). After 11 years in a non-irrigated vineyard, Martínez de Toda and Sancha (1999) observed a higher average yield in simulated mechanical pruning than in hand-pruned vines, although the first years' yields showed no differences between treatments. In the first season of the study, the bunch mass of T1 was smaller (Table 5) but, as mentioned earlier, these vines had been mechanically pruned in the previous years. In the second and third seasons,

TABLE 5

Bunch number and mass of Merlot vines hand or mechanically pruned in El Huique, Chile.

\begin{tabular}{|c|c|c|c|c|c|c|c|c|c|}
\hline \multirow[b]{2}{*}{ Treatment } & \multicolumn{3}{|c|}{ Bunches per plant } & \multicolumn{3}{|c|}{ Bunch mass (g) } & \multicolumn{3}{|c|}{ Yield per vine (kg) } \\
\hline & $2013 / 14$ & $2014 / 15$ & $2015 / 16$ & $2013 / 14$ & $2014 / 15$ & $2015 / 16$ & $2013 / 14$ & $2014 / 15$ & $2015 / 16$ \\
\hline 1 (SSS) & $37 \mathrm{~b}$ & $64 \mathrm{~d}$ & $85 \mathrm{a}$ & $106.5 \mathrm{~b}$ & $133.7 \mathrm{a}$ & $158.1 \mathrm{a}$ & $4.0 \mathrm{c}$ & $8.4 \mathrm{c}$ & $13.5 \mathrm{a}$ \\
\hline $2(\mathrm{SLH})$ & $37 \mathrm{~b}$ & $115 a b$ & $102 \mathrm{a}$ & $106.5 \mathrm{~b}$ & $127.7 \mathrm{a}$ & $130.8 \mathrm{~b}$ & $4.0 \mathrm{c}$ & $14.8 \mathrm{a}$ & $13.5 \mathrm{a}$ \\
\hline $3(\mathrm{HHH})$ & $95 \mathrm{a}$ & $110 \mathrm{~b}$ & $89 \mathrm{a}$ & $124.9 \mathrm{a}$ & $95.4 \mathrm{~b}$ & $134.5 \mathrm{~b}$ & $11.8 \mathrm{a}$ & $10.6 \mathrm{bc}$ & $11.9 \mathrm{a}$ \\
\hline $4(\mathrm{HLH})$ & $95 \mathrm{a}$ & $87 \mathrm{c}$ & $97 \mathrm{a}$ & $124.9 \mathrm{a}$ & $94.8 \mathrm{~b}$ & $140.5 \mathrm{~b}$ & $11.8 \mathrm{a}$ & $8.2 \mathrm{c}$ & $13.6 \mathrm{a}$ \\
\hline 5 (LLL) & $83 \mathrm{a}$ & $98 \mathrm{bc}$ & $91 \mathrm{a}$ & $112.5 \mathrm{ab}$ & $121.6 \mathrm{a}$ & $141.9 \mathrm{~b}$ & $9.4 \mathrm{~b}$ & $12.0 \mathrm{ab}$ & $12.9 \mathrm{a}$ \\
\hline $6(\mathrm{LHH})$ & $83 a$ & $136 \mathrm{a}$ & $100 \mathrm{a}$ & $112.5 \mathrm{ab}$ & $105.9 \mathrm{~b}$ & $135.8 \mathrm{~b}$ & $9.4 \mathrm{~b}$ & $14.8 \mathrm{a}$ & $13.5 \mathrm{a}$ \\
\hline
\end{tabular}

The S, L and H for each treatment refer to S: hand-pruning, 12 two-bud spurs per plant; $\mathrm{H}$ : mechanical pruning $25 \mathrm{~cm}$ above the cordon wire; L: mechanical pruning $12 \mathrm{~cm}$ above the cordon wire; with each capital letter corresponding to one season from the three consecutive years of the study.

Means with the same letters in the columns are not significantly different. Fisher's LSD $(\mathrm{p} \leq 0.05)$

\section{TABLE 6}

Bunch number and mass of Merlot vines hand or mechanically pruned in El Huique, Chile, average three seasons (from $2013 / 14$ to $2015 / 16$ ).

\begin{tabular}{llll}
\hline Treatment & Bunches per plant & Bunch mass $(\mathrm{g})$ & Yield per vine $(\mathrm{kg})$ \\
\hline $1(\mathrm{SSS})$ & $62 \mathrm{~d}$ & $132.7 \mathrm{a}$ & $8.7 \mathrm{~b}$ \\
$2(\mathrm{SLH})$ & $85 \mathrm{c}$ & $121.6 \mathrm{bc}$ & $10.7 \mathrm{a}$ \\
$3(\mathrm{HHH})$ & $98 \mathrm{ab}$ & $118.3 \mathrm{bc}$ & $11.4 \mathrm{a}$ \\
$4(\mathrm{HLH})$ & $93 \mathrm{abc}$ & $119.9 \mathrm{bc}$ & $11.2 \mathrm{a}$ \\
$5(\mathrm{LLL})$ & $91 \mathrm{bc}$ & $125.3 \mathrm{ab}$ & $11.4 \mathrm{a}$ \\
$6(\mathrm{LHH})$ & $106 \mathrm{a}$ & $118.1 \mathrm{c}$ & $12.5 \mathrm{a}$ \\
\hline
\end{tabular}

The S, L and $\mathrm{H}$ for each treatment refer to S: hand-pruning, 12 two-bud spurs per plant; $\mathrm{H}$ : mechanical pruning $25 \mathrm{~cm}$ above the cordon wire; L: mechanical pruning $12 \mathrm{~cm}$ above the cordon wire; with each capital letter corresponding to one season from the three consecutive years of the study.

Means with the same letters in the columns are not significantly different. Fisher's LSD $(p \leq 0.05)$ 
bunches from the shorter pruning elements in general were heavier (Table 5). Average bunch mass was higher in T1, and bunches from T5 were the closest in mass to T1, but the mass of individual bunches from vines pruned by hand was not enough to increase total fruit production per plant in mechanical pruning treatments (Table 6). Similar results were obtained by Archer and Van Schalkwyk (2007) in a Merlot vineyard, where the bunch number of mechanically pruned vines was almost double the number in hand-pruned vines and bunch mass was reduced $20 \%$ in mechanically pruned vines, resulting in a $20 \%$ yield increase. Our results for the cumulative yields show $45 \%$ yield increase in $\mathrm{T} 6$ compared to T1 (hand-pruned vines), whilst in vines always pruned high (T3), the increase compared to T1 was only $32 \%$ (Table 7).

The overall high yield on mechanically pruned vines was not stable in time in relation to the highest potential yield (Tables 5 and 6). In the second season, T2 and T5 (both mechanically pruned low) gave higher yields than T3 (traditional mechanically pruned high). In the 2015/2016 season, all treatments produced particularly high yields and no differences were observed between treatments. Overall, bunches in this third season of study were heavier than in previous seasons (total average of 140 compared to $114 \mathrm{~g}$ in the first and second seasons, Table 5), which partially explains the heavy crop observed. In the 2015/2016 season, bunches from the hand spur-pruned vines doubled in number and were about 30\% heavier than in the 2013-2014 season, when hand pruning had first been carried out in this previously mechanised vineyard (Table 5). Other authors have also observed a strong seasonal effect on yield whilst working on mechanically pruned vines, and have detected large differences between seasons in hand-pruned treatments (Martínez de Toda \& Sancha, 1999; Keller et al., 2004; Terry \& Kurtural, 2011). A considerable increase in yield, season after season, was observed when previously machine-pruned vines were hand-pruned for three consecutive years - a sign of the improved pruning material obtained and the unexploited production potential of these vines. Traditional mechanical pruning ( $25 \mathrm{~cm}$ above the cordon wire) presented the highest yield in the first season of the study, although the larger fruit production was not obtained from high mechanical pruning after the second and third seasons (Table 5). This finding supports the concept of the decay effect suffered by these vines, which is eventually reflected in the yield. The fruit production of T6, vines mechanically pruned low one season and then pruned high for two consecutive seasons, showed the largest grape production in 2014/2015 and when adding the results from the three seasons (Table 7). A low mechanical pruning appears to increase vine shoot number, helping to maintain large and regular fruit production over the years.

Although mechanical pruning at any height increased fruit production in general, basic fruit composition was not affected (data not shown; ranges were: 21.4 to $21.7^{\circ} \mathrm{Brix}$ TSS; 6.0 to $6.3 \mathrm{~g} / \mathrm{L} \mathrm{TA} ; 3.52$ to $3.58 \mathrm{pH}$ ), largely concordant with other studies of mechanical pruning effects on fruit composition (Morris et al., 1975; Martínez de Toda \& Sancha, 1999; Lopes et al., 2000; Keller et al., 2004; Archer \& Van Schalkwyk, 2007). The TSS, TA and $\mathrm{pH}$ were equal among treatments, except for a slightly lower TSS in the fruit from T5 and T6 in the first season (data not shown). Nevertheless, the extremely high yields observed in all treatments during the third season were reflected in the low TSS, at barely $18^{\circ} \mathrm{Brix}$, which is a sign of widespread overcropping in all treatments. Other studies have shown a tendency for mechanised pruning to marginally delay ripening, but also pointed out a larger seasonal effect (Keller et al., 2004).

Occasionally it is possible to find vineyards in which the yields of mechanically pruned vines are maintained over time, but traditional mechanical pruning (equivalent to T3) has mostly been associated with a decline in production after a few seasons. In the second and third seasons in this study, traditional mechanical pruning did not show any increase in production compared to hand pruning (Table 5). High mechanical pruning generated more bunches per plant and yield per vine than hand pruning, but yield was not sustained over time (Table 5). In the second season of the study, the yield increase compared to manual pruning was higher in the T6 plants, which had been pruned low the previous season

TABLE 7

Annual and cumulative yield equivalent of Merlot vines hand or mechanically pruned in El Huique, Chile.

\begin{tabular}{lllll}
\hline & Yield 2013/14 & Yield 2014/15 & Yield 2015/16 & $\begin{array}{c}\text { Cumulative production } \\
\text { (three seasons) }\end{array}$ \\
\cline { 2 - 5 } Treatment & $\mathrm{t} / \mathrm{ha}$ & $\mathrm{t} / \mathrm{ha}$ & $\mathrm{t} / \mathrm{ha}$ & $\mathrm{t} / \mathrm{ha}$ \\
\hline $1(\mathrm{SSS})$ & $13.4 \mathrm{c}$ & $28.1 \mathrm{c}$ & $45.0 \mathrm{a}$ & $86.5 \mathrm{c}$ \\
$2(\mathrm{SLH})$ & $13.4 \mathrm{c}$ & $49.2 \mathrm{a}$ & $44.9 \mathrm{a}$ & $107.5 \mathrm{~b}$ \\
$3(\mathrm{HHH})$ & $39.4 \mathrm{a}$ & $35.3 \mathrm{bc}$ & $39.8 \mathrm{a}$ & $114.5 \mathrm{~b}$ \\
$4(\mathrm{HLH})$ & $39.4 \mathrm{a}$ & $28.8 \mathrm{c}$ & $45.3 \mathrm{a}$ & $113.5 \mathrm{~b}$ \\
$5(\mathrm{LLL})$ & $31.2 \mathrm{~b}$ & $39.9 \mathrm{bc}$ & $42.8 \mathrm{a}$ & $114.1 \mathrm{~b}$ \\
$6(\mathrm{LHH})$ & $31.2 \mathrm{~b}$ & $49.1 \mathrm{a}$ & $45.1 \mathrm{a}$ & $125.4 \mathrm{a}$ \\
\hline
\end{tabular}

The S, L and H for each treatment refer to S: hand-pruning, 12 two-bud spurs per plant; H: mechanical pruning 25 cm above the cordon wire; L: mechanical pruning $12 \mathrm{~cm}$ above the cordon wire; with each capital letter corresponding to one season from the three consecutive years of the study.

Means with the same letters in the columns are not significantly different. Fisher's LSD $(p \leq 0.05)$ 
(Table 5). Nodes per spur and bud burst percentage were affected by pruning, and both altered bunch number, thereby modifying yield and fruit composition.

In general, hand pruning to renew vineyards with reduced productivity has been successful, but in the season when hand pruning was done, and sometimes also in the following season, yields dropped considerably. In this study, the treatment with low pruning and then high pruning in the second and third seasons (T6) showed the highest cumulative fruit production (Table 7). Treatments such as $\mathrm{T} 4$, with a different order of pruning over the evaluated seasons, had a lower average yield (Table 7), probably due in part to the slow ability of the vineyard to recover.

The second-crop bunches were recorded along with bunch number. These smaller bunches delay maturity and compromise juice composition, particularly when vineyards are mechanically harvested and no selection is possible. The number and mass of second-crop bunches (bunches on lateral shoots) were not altered (data not shown), although T5 and T6 produced a higher number of second fruit than hand-pruned vines. This could be due in part to strengthened vines that will have more fruit during the season as a result of the growth of lateral shoots. However, the difference was irrelevant, $<100 \mathrm{~g}$ per plant. The TSS, TA and $\mathrm{pH}$ did not differ between treatments (data not shown; ranges were: 21.0 to $21.4^{\circ} \mathrm{Brix}$ TSS; 6.4 to $6.6 \mathrm{~g} / \mathrm{L} \mathrm{TA} ; 3.49$ to $3.52 \mathrm{pH}$ ) and were close to commercial crop fruit values. In general, previous studies in which leaf area of lateral shoots was evaluated did not show differences between hand pruning and mechanical hedging (Lopes et al., 2000; Poni et al., 2004), a situation that was reflected in the overall absence of differences in fruit from lateral shoots.

\section{CONCLUSIONS}

For a long time there have been ideas about how to avoid the need for hand pruning. Currently, productive systems envision mechanisation as a tool to reduce costs and overcome labour shortages. Many wine grape growers have implemented mechanised harvesting, but have hesitated to embrace pruning mechanisation. The hesitation in the implementation of total mechanisation can be ascribed partially to concerns about its sustainability over time and the need for subsequent hand pruning to correct vine balance. This study shows the feasibility of implementing a mechanical pruning system and sustaining yield over the years without any manual operation requirements to adjust the crop or to renew plant-pruning material. Operations in the vineyards can be reduced to mechanical pruning and harvest without further complex interventions. The possibility of overcropping requires seasonal revision of pruning and other cultivation practices in accordance with grapevine growth and environmental conditions. An adjustment in mechanical pruning with regard to cutting height is a feasible alternative to obtain regular and sustainable yields with considerably lower labour inputs in the vineyard.

\section{LITERATURE CITED}

Archer, E. \& Van Schalkwyk, D., 2007. The effect of alternative pruning methods on the viticultural and oenological performance of some wine grapes varieties. S. Afr. J. Enol. Vitic. 28, 107-127.
CIREN, 2010. Estudio Agrológico Región VI, descripciones de suelos, materiales y símbolos, actualización. Pub. CIREN n 114 . Santiago, Chile.

Clingeleffer, P.R., 2000. Mechanization of wine and raisin production in Australian vineyards. In: Rantz, J.M. (ed.). Proc. ASEV 50 th Anniv. Annual Meeting, June 2000, Seattle Washington, U.S.A. pp. 165 - 169.

Di Rienzo, J.A., Casanoves, F., Balzarini, M.G., Gonzalez, L., Tablada, M. \& Robledo, C.W., 2016. InfoStat versión 2016. Grupo InfoStat, FCA, Universidad Nacional de Córdoba, Argentina. Available at: http://www infostat.com.ar

Di Rienzo, J.A., Macchiavelli R. \& Casanoves F., 2011. Modelos lineales mixtos: Aplicaciones en InfoStat. $1^{\text {a }}$ Ed, Córdoba. Grupo Infostat.

Dokoozlian, N., 2013. The evolution of mechanized vineyard production systems in California. Acta Hortic. 978, 265-278.

Freeman, B.M. \& Cullis, B.R., 1981. Effect of hedge shape for mechanical pruning of vinifera vines. Am. J. Enol. Vitic. 32, 21-25.

Gatti, M., Civardi, S., Bernizzoni, F. \& Poni, S., 2011. Long-term effects on mechanical winter pruning on growth, yield, and grape composition of Barbera grapevines. Am. J. Enol. Vitic. 62, 199-206.

Howell, G.S., 2001. Sustainable grape productivity and the growth-yield relationship: A review. Am. J. Enol. Vitic. 52, 165-174.

Intrieri, C. \& Poni, S., 1990. A new integrated approach between training system and mechanical equipment for full mechanization of quality vineyards. In: Williams, P.J., Davidson, D.M. \& Lee, T.H. (eds). Proc. $7^{\text {th }}$ Aust. Wine Ind. Tech. Conf., August 1989, Adelaide, Australia. pp. 35 - 50.

Keller, M., Mills, L.J., Wample, R.L. \& Spayd, S.E., 2004. Crop load management in Concord grapes using different pruning techniques. Am. J. Enol. Vitic. 55, 35-50

Lopes, C., Melicias, J., Aleixo, A., Laureano, O. \& De Castro, R., 2000 Effect of mechanical hedge pruning on growth, yield and quality of Cabernet Sauvignon grapevines. Acta Hortic. 526, 261-268.

Martínez de Toda, F. \& Sancha, J.C., 1999. Long-term effects of simulated mechanical pruning on Grenache vines under drought conditions. Am. J. Enol. Vitic. 50, 87-90.

Morris, J.R., 2007. Development and commercialization of a complete vineyard mechanization system. HortTechnology 17, 411-420.

Morris, J.R. \& Cawthon, D. L., 1981. Yield and quality response of Concord grapes (Vitis labrusca L.) to mechanized vine pruning. Am. J. Enol. Vitic. 32, 280-282.

Morris, J.R., Cawthon D.L. \& Fleming J.W., 1975. Effect of mechanical pruning on yield and quality of 'Concord' grapes. Arkansas Farm. Res. 24, 12-13.

Poni, S., Bernizzoni, F., Presutto, P. \& Rebucci, B., 2004. Performance of Croatina under short-cane mechanical hedging: A successful case of adaptation. Am. J. Enol. Vitic. 55, 379-388.

Reynolds, A.G., 1988. Response of Okanagan Riesling vines to training system and simulated mechanical pruning. Am. J. Enol. Vitic. 39, 205-212.

SAG (Servicio Agrícola y Ganadero), 2015. Catastro vitícola nacional. División de protección agrícola y forestall, subdepartamento de viñas, vinos y bebidas alcohólicas. Available at: http://www.sag.cl/content/catastroviticola-nacional-2015

Terry, D.B. \& Kurtural, S.K., 2011. Achieving vine balance of Syrah with mechanical canopy management and regulated deficit irrigation. Am. J. Enol. Vitic. 62, 426-437.

Winkler, A.J., Lamouria, L.H. \& Abernathy, G.H., 1957. Mechanical grape harvest - problems and progress. Am. J. Enol. Vitic. 8, 182-187. 